\title{
Bioaccumulation of Trace Metals in Groenlandia densa Plant Reintroduced in Western Pomerania
}

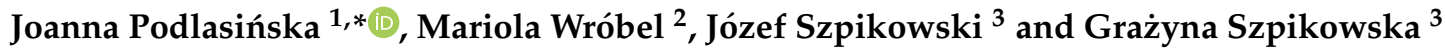 \\ 1 Department of Environmental Management, Faculty of Environmental Management and Agriculture, \\ West Pomeranian University of Technology in Szczecin, 17 Słowackiego Street, 71-434 Szczecin, Poland \\ 2 Department of Landscape Architecture, Faculty of Environmental Management and Agriculture, \\ West Pomeranian University of Technology in Szczecin, 17 Słowackiego Street, 71-434 Szczecin, Poland; \\ mariola.wrobel@zut.edu.pl \\ 3 Institute of Geoecology and Geoinformation, Adam Mickiewicz University in Poznań, 1, ul. Wieniawskiego 1, \\ 61-712 Poznań, Poland; grania@amu.edu.pl (J.S.); szpiko@amu.edu.pl (G.S.) \\ * Correspondence: Joanna.Podlasinska@zut.edu.pl; Tel.: +48-914496353
}

Citation: Podlasińska, J.; Wróbel, M.; Szpikowski, J.; Szpikowska, G.

Bioaccumulation of Trace Metals in Groenlandia densa Plant Reintroduced in Western Pomerania. Processes 2021, 9, 808. https://doi.org/10.3390/ pr9050808

Academic Editor: Robert Biczak

Received: 15 April 2021

Accepted: 30 April 2021

Published: 5 May 2021

Publisher's Note: MDPI stays neutral with regard to jurisdictional claims in published maps and institutional affiliations.

Copyright: (C) 2021 by the authors. Licensee MDPI, Basel, Switzerland. This article is an open access article distributed under the terms and conditions of the Creative Commons Attribution (CC BY) license (https:/ / creativecommons.org/licenses/by/ $4.0 /)$.

\begin{abstract}
The phytoremediation role of aquatic plants in situ is extremely important today when, due to repeated droughts and periodical shrinkage of surface water resources, the load of biogenic and toxic substances in these waters is increasing dramatically. The aim of the study was to assess the bioaccumulation of heavy metals $(\mathrm{Cd}, \mathrm{Cr}, \mathrm{Cu}, \mathrm{Hg}, \mathrm{Mn}$ and $\mathrm{Zn}$ ) by the Groenlandia densa reintroduced in the area of its historical occurrence in the habitat of rivers characterized by Ranunculion fluitantis vegetation. Research material was collected from 3 sites in the Natura 2000 area in Western Pomerania on areas differing in anthropogenic load, from sites on streams in agricultural, urbanized and forested catchments. The study showed varying content of trace metals in Groenlandia densa. Plants and sediments collected from the site with the highest anthropogenic load, located in an urbanized catchment, contained more metals. The tolerance of Groenlandia densa to elevated Mn levels in water/sediment was confirmed.
\end{abstract}

Keywords: Groenlandia densa; aquatic macrophytes; bioaccumulation; heavy metals; ecological studies; environmental chemistry; exposure and bioaccumulation; risk assessment

\section{Introduction}

Groenlandia densa classified within the family Potamogetonaceae, is a species under strict legal protection and requires active conservation in accordance with the Ordinance of the Minister of Environment of 9 October 2014 on plant species conservation [1]. It is a critically endangered species listed in the Polish Red List of Ferns and Flowering Plants [2] and in the Polish Red Book of Plants [3]. It is an evergreen hydromacrophyte with long, densely leafy stems with opposite leaves, rooting in the gravel and sand substrate, with high light requirements, a rheophilic species, an indicator species of clean waters with low trophy. The stems branch out, they have the tendency to fragment and spread in this manner thus colonizing new sites. Opposite-leaved pondweed Groenlandia densa ( $G$. densa) is a taxon found in riverine assemblages of hydromacrophytes characterizing the protected Natura 2000 habitat "Lowland and submontante rivers with buttercup assemblages (Ranunculion fluitantis)" (habitat code: 3260). Historically, this species was found in the West Pomerania in the area of Biały Bór and Chociwel, but it has not been recorded in Poland for the last 30 years. The habitat of Ranunculion fluitantis rivers is one of the subjects of conservation measures included in the LifeDrawaPl project, entitled "Active conservation of buttercup habitats and opening the ecological corridor of the Drawa River in Poland." As part of the project, a program of opposite-leaved pondweed $G$. densa reintroduction was developed on selected riverine systems of Grabowa, Radew and Chociel Rivers on Natura 2000 sites 
PLH 320022 "Dolina Radwi, Chocieli i Chotli" and PLH 320003 "Dolina Grabowej”. Populations of opposite-leaved pondweed used for the reintroduction were collected in 2017 from sites in several rivers of Germany and Austria, preceded by genetic studies confirming its high affinity with the former Polish population present until the end of 1980s and documented with herbarium collections which were used as comparative material for the studies [4]. The biological material was acclimatized and propagated at the Botanical Garden of the Adam Mickiewicz University in Poznan and at the Geoecological Station of the Adam Mickiewicz University in Storków and it was used for planting on the sites where conditions analogous to its habitat requirements had been found [5]. One of the aspects analyzed before making the decision on the reintroduction of the opposite-leaved pondweed G. densa, apart from its restoration to the former localities and the attempt at preserving the species diversity of riverine macrophyte phytocenoses was the bioindication role of the species confirmed by research. It is an approved indicator of high content of iron and manganese compounds in flowing waters, and it has further capacity to bioaccumulate pollutants such as nickel and cadmium [6-9]. Most of the studies on the suitability of G. densa to assess the ecotoxicity of polluted waters were ex situ studies focusing on the accumulation of $\mathrm{Ni}, \mathrm{Cd}$ and $\mathrm{Cu}$ [7-9]. There is limited information about responses of this plant to zinc, mercury and chromium.

The phytoremediation role of aquatic plants appears especially important nowadays, in view of repeating droughts and periodic restriction of surface water resources, both riverine and lacustrine, the concentration of the load of biogens and toxic substances in their waters has been increasing dramatically, leading to reduced biological live levels and the capacity for natural regeneration and normal functioning of aquatic ecosystems. The advantage of $G$. densa over other hydromacrophytes is the fact of year-round photosynthetic activity, as it is an evergreen species and can clean the water when other species disappear for the winter. It is a species of medium trophic habitat, so macrophytes from eutrophic waters-e.g., Lemna minor or Myriophyllum, do not occur on the same sites with G. densa.

The study aimed at the assessment of heavy metal bioaccumulation capacity of opposite-leaved pondweed (Groenlandia densa), successfully reintroduced to the area of its former habitat of Ranunculion fluitantis rivers.

\section{Materials and Methods}

\subsection{Material Sampling}

In the study, leafy stems and adventitious roots of opposite-leaved pondweed G. densa were used, collected from three sites of reintroduction of the species located in the water courses in the Natura 2000 site "Dolina Radwi, Chotli i Chocieli" PLH 320022 and "Dorzecze Parsęty" PLH 320007. This area is characterized by diverse early post-glacial relief with numerous post-glacial forms including moraine uplands and kame hills, finger lakes, and it is particularly distinguished by the abundance of springs and natural seepages of confined waters feeding the Radew and Grabowa River systems [10,11].

As G. densa is classified is a species under strict legal protection the consent to collect plant material was issued by the General Director for Environmental Protection (decision no. DZP-WG.6400.3.2020.EP). The biological material was collected once in May 2020 from sites differing in water physicochemical parameters and bottom sediments, water course depth and bottom structure, water volume flow rate and the mean of the land usage (Table 1), crossed by the water courses with research sites (Figure 1):

- $\quad$ site I: Chwalimski Potok flowing into Parseta River at Storkowo, located in agricultural basin, on areas characterized by extensive agricultural use (humid hay meadows), fed with groundwaters;

- $\quad$ site II: Stara Radew at Rosnowo, site in riverine gallery forests, fed with underground seepages, in an agricultural basin with developed municipal and road infrastructure;

- site III: rocky spring feeding an unnamed creek flowing directly into the Radew River, on areas with silviculture, in acid beech forests and spruce stands. 
The reintroduction was performed in September 2017 at Site I and in June 2018 at sites II and III. The Site I (Chwalimski Potok) was treated as a control because it is the place of reproduction and breeding of $G$. densa specimens from which plants were taken for further reintroduction at selected sites. Prior to initial sampling in 2020, G. densa had been exposed to the discussed contaminants for about 2.5 years at site I and 2 years at sites II and III. Studies on physicochemical properties of waters were conducted directly in the field and in the laboratory of the UAM Geoecological Station in Storkow. Field studies included measurements of temperature, electrolytic conductivity, $\mathrm{pH}$, dissolved oxygen, and oxygenation using a field meter with a multi-parameter probe HI9898 (Hanna Instruments). Redox potential in water and sediments was measured using a CX-461 multifunction meter (Elmetron) with an ERPt-111 combined electrode. River water samples for laboratory analyses were collected in $1 \mathrm{~L}$ plastic bottles. All samples were filtered by a $0.45-\mu \mathrm{m}$ Whatman's cellulose membrane filters. Bicarbonates were determined using an alkalinity titration method. The determination of nitrates was made using ion chromatography (DX-120 ion chromatograph, Dionex). Nitrites were determined by the colorimetric method using the Macherey-Nagel test, phosphates-by spectrophotometric method (spectrophotometer-Nanocolor VIS, Macherey-Nagel). The following Polish standards were used in the laboratory procedure: PN-EN ISO 10304-1:2009E, PN-EN ISO 6878:2006P, PN-EN ISO 9963-1:2001P [12-14].

Table 1. Site characteristics.

\begin{tabular}{|c|c|c|c|}
\hline Tested Feature & $\begin{array}{c}\text { Site I } \\
\text { Agricultural } \\
\text { Water Shed }\end{array}$ & $\begin{array}{c}\text { Site II } \\
\text { Urbanized Water } \\
\text { Shed }\end{array}$ & $\begin{array}{c}\text { Site III } \\
\text { Forest Water } \\
\text { Shed }\end{array}$ \\
\hline $\begin{array}{l}\text { The surface of the patch with } \\
\text { G. densa }\left(\mathrm{m}^{2}\right)\end{array}$ & 4 & 6 & 1 \\
\hline $\begin{array}{l}\text { Share of G. densa according to } \\
\text { Braun-Blanquet scale }\end{array}$ & 5 & 4 & 1 \\
\hline Bottom structure & sandy & gravel and stone & pebble and stone \\
\hline Organic sediments & negligible & much & average \\
\hline Depth of watercourse (m) & $0.1-0.15$ & $0.5-0.6$ & $0.1-0.15$ \\
\hline In-stream water temperature $\left({ }^{\circ} \mathrm{C}\right)$ & 10.9 & 10.8 & 10.3 \\
\hline $\mathrm{pH}$ & 8.15 & 7.80 & 7.66 \\
\hline Electrical conductivity $\left[\mu \mathrm{S} \cdot \mathrm{cm}^{-2}\right]$ & 404 & 397 & 392 \\
\hline Dissolved oxygen $\left[\mathrm{mg} \mathrm{O}_{2}\right]$ & 8.10 & 7.81 & 8.61 \\
\hline Oxygenation [\%] & 68.2 & 68.4 & 76.6 \\
\hline Flow rate $(\mathrm{m} / \mathrm{s})$ & 0.02 & 0.71 & 0.20 \\
\hline Bicarbonates $\left(\mathrm{mg} / \mathrm{dm}^{3} \mathrm{HCO}_{3}{ }^{-}\right)$ & 187.32 & 200.14 & 167.19 \\
\hline Nitrates $\left(\mathrm{mg} / \mathrm{dm}^{3} \mathrm{NO}_{3}^{-}\right)$ & 27.23 & 1.03 & 1.14 \\
\hline Nitrites $\left(\mathrm{mg} / \mathrm{dm}^{3} \mathrm{NO}_{2}^{-}\right)$ & 0.010 & 0.020 & 0.005 \\
\hline Phosphates $\left(\mathrm{mg} / \mathrm{dm}^{3} \mathrm{PO}_{4}{ }^{3}\right)$ & 0.24 & 0.25 & 0.10 \\
\hline
\end{tabular}

Following the collection of the plant material, it was rinsed with deionized water in order to remove contaminants and sediments. Whole plants were used in the study and also the separated parts of $G$. densa, the youngest $5-6 \mathrm{~cm}$ apical parts, the remaining leafy stem and the leafless part of this plant. Plants taken from different locations differed in biometric features, as the length and width of the leaf blade, as well as the length of the internode (Table 2).

\subsection{Sample Preparation and Analysis}

The plant material was dried in a ventilation drier at the temperature of $70{ }^{\circ} \mathrm{C}$ until constant weight was obtained, followed by disintegration in a laboratory mill. Plant samples were mineralized in a MILESTONE microwave oven in nitric acid $(4 \mathrm{~mL})$ with addition of perhydrol (1 mL).

Sediment samples were dried in room temperature. A fraction below $2 \mathrm{~mm}$ was collected for testing. Sediment samples were mineralized in a MILESTONE microwave oven in the mixture of nitric and perchloric acid (4:1) with the addition of perhydrol ( $1 \mathrm{~mL})$. 


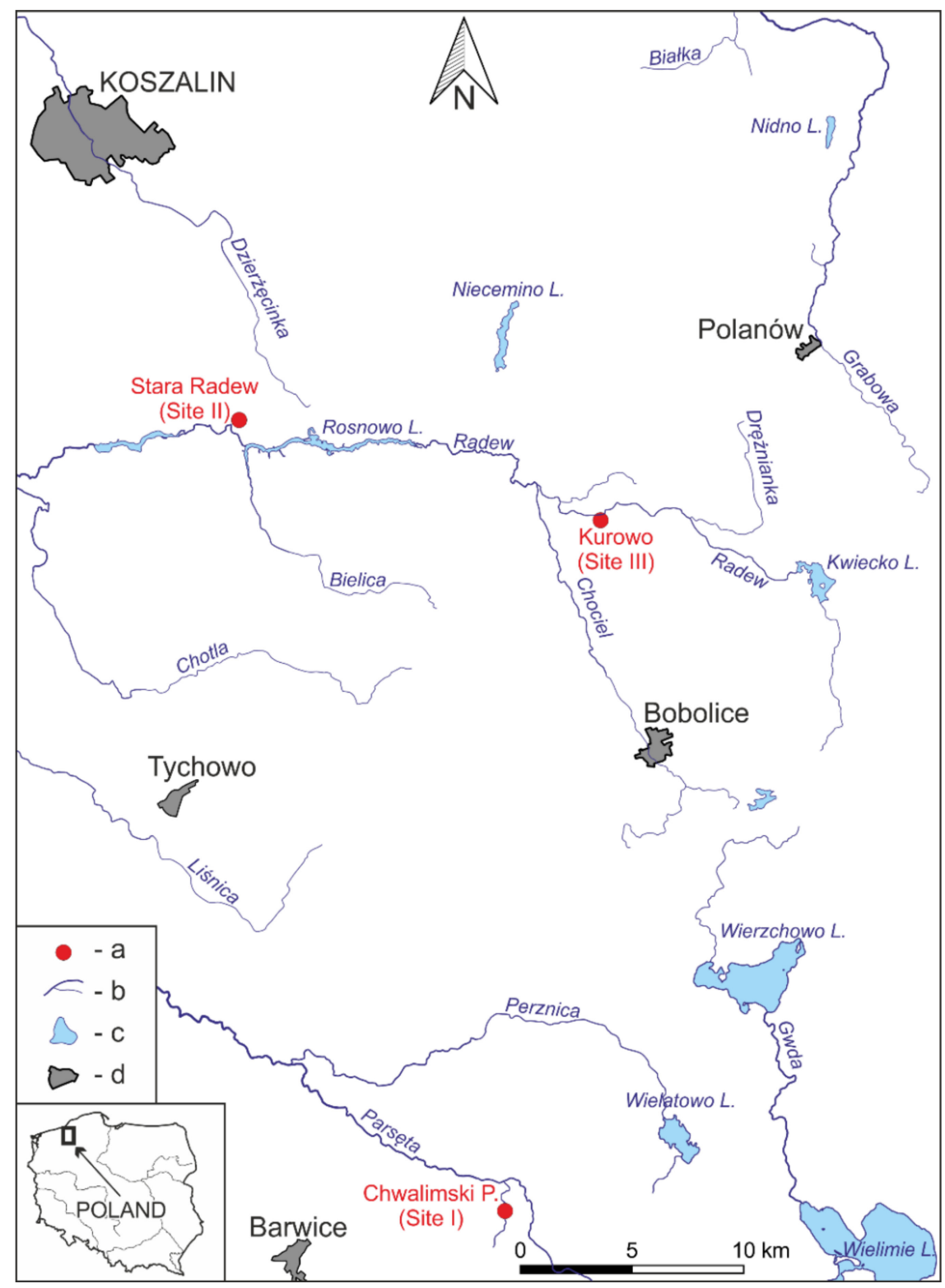

Figure 1. Location of sampling sites. Legend: $\mathrm{a}$ —sampling sites; b—rivers, $\mathrm{c}$-lakes, $\mathrm{d}$ —urban areas.

Table 2. Biometric data of opposite-leaved pondweed.

\begin{tabular}{lccc}
\hline \multicolumn{1}{c}{ Sampling Site } & $\begin{array}{c}\text { Blade Length }^{\mathbf{1}} \\
(\mathbf{m m})\end{array}$ & $\begin{array}{c}\text { Width of Leaf Blade } \\
\mathbf{1}\end{array}$ & $\begin{array}{c}\text { Internode Length }^{\mathbf{1}^{1}} \\
(\mathbf{m m})\end{array}$ \\
\hline Site I Chwalimski Potok & $12-19$ & $5-8$ & $2-5$ \\
\hline Site II Stara Radew & $16-24$ & $7-12$ & $3-10$ \\
\hline Site III Kurowo 1 & $14-20$ & $6-9$ & $3-13$ \\
\hline
\end{tabular}

${ }^{1}$ measured for 10 plants in the middle of the shoot, about $5-10 \mathrm{~cm}$ from the tip.

Determinations of the contents of tested trace elements $(\mathrm{Cd}, \mathrm{Cu}, \mathrm{Cr}, \mathrm{Mn}$ and $\mathrm{Zn})$ in the plants and sediments was performed with an iCE 3000 atomic absorption spectrometer, and of mercury with an AMA 256 apparatus.

Limits of detection (LOD) for the determined elements were: $\mathrm{Cd}-0.0028$; $\mathrm{Cu}-0.0045$; $\mathrm{Cr}-0.0054 ; \mathrm{Mn}-0.0016 ; \mathrm{Zn}-0.0033 \mathrm{mg} \cdot \mathrm{kg}^{-1}$. On the other hand, the device sensitivity for individual elements was: $\mathrm{Cd}-0.013 ; \mathrm{Cu}-0.033 ; \mathrm{Cr}-0.05 ; \mathrm{Mn}-0.02 ; \mathrm{Zn}-0.01 \mathrm{mg} \cdot \mathrm{kg}^{-1}$.

The parameters of the AMA 254 mercury analyzer for sediment and plant dry mass were as follows: drying $-30 \mathrm{~s}$, decomposition-150 s, determination $-45 \mathrm{~s}$. 
The samples were analyzed in three replications. All results for G. densa and sediments were calculated on a dry weight basis.

The relative error all metals was less than $7 \%$ and the recoveries of the reference materials (tea leaves (INCT-TL-1) produced by the Institute of Nuclear Chemistry and Technology in Poland and loamy sand (CRM 036-050) manufactured by the Resource Technology Corporation (USA and UK) were between 91-103\%.

\subsection{The Bioconcentration Factor (BCF)}

The bioconcentration factor (BCF) provides an index of the ability of the plant to accumulate the metal with respect to the metal concentration in the substrate. BCF $>1$ indicates heavy metal accumulation. The BCF was calculated as follows $[15,16]$ :

$$
B C F=\frac{\text { Concentration of metal in plant tissue }}{\text { Initial concentration of metal in external solution or substrate }}
$$

\subsection{The Geochemical Index (Igeo) Values and Contamination Factor}

A geochemical index, a pollution index and an indicator of an impact on benthic organisms were used to evaluate the sediments.

Geochemical index (Igeo) is defined using the following formula [17]:

$$
I g e o=\log 2 \frac{C m}{1.5 G M}
$$

where:

$\mathrm{Cm}$ - content of analyzed metal $\left(\mathrm{mg}^{\mathrm{kg}} \mathrm{kg}^{-1}\right)$,

GM-geochemical background $\left(\mathrm{mg} \cdot \mathrm{kg}^{-1}\right)$.

The Igeo values are divided into seven classes, i.e., non-polluted sediment class 0 (Igeo $\leq 0)$, poorly polluted sediment class $1(0<$ Igeo $<1)$, moderately contaminated sediment class $2(1<$ Igeo $<2)$, averagely contaminated sediment class $3(2<$ Igeo $<3)$, highly contaminated sediment class $4(3<$ Igeo $<4)$, very heavily polluted class $5(4<$ Igeo $<5)$, extremely contaminated sediment class 6 (Igeo $\geq 5$ ).

Contamination factor was determined as a ratio of the total metal content to the geochemical background value [18]:

$$
C F=\frac{C m}{G M}
$$

where:

$\mathrm{Cm}$ - content of analyzed metal $\left(\mathrm{mg} \cdot \mathrm{kg}^{-1}\right)$,

GM-geochemical background $\left(\mathrm{mg} \cdot \mathrm{kg}^{-1}\right)$.

Bottom sediments were classified on the basis of the obtained values of contamination factor ( $\mathrm{CF}$ ), according to the following ranges: $\mathrm{CF}<1$-class I (low contamination), $1 \leq \mathrm{CF} \leq 3$-class II (medium contamination), $3<\mathrm{CF}<6$-class III (significant contamination), $C F \geq 6$-class IV (very high contamination).

The investigated sediments were also assessed for the ecotoxicological criteria based on the TEC (threshold effect concentration), MEC (midpoint effects concentrations) and PEC (probable effect concentration) indices [19]. The TEC (Threshold Effect Concentration) index value constitutes a threshold value used to identify the pollutant concentrations below which no adverse effects on benthic organisms are expected, MEC (midpoint effects concentrations) determines the concentration which is the intermediate value between the threshold values specified in TEC and PEC, while PEC presents such element or chemical compound content above which toxic effects on the organism is observed. 


\subsection{Statistical Analysis}

Values shown in the figures and tables represent the average values and standard deviation (SD) for each trace metal concentration. The simple linear correlation coefficient (r) was calculated for assessing the relationship between heavy metals in plant and sediments and water variables. All statistical calculations were carried out using Statistica 12 for Windows.

\section{Results and Discussion}

Plant species collected from each sampling site and their heavy metal concentration are listed in Table 3, together with the results of sediment and water analyses.

Table 3. Distribution of heavy metal in G. densa, sediments and water collected from 3 sites.

\begin{tabular}{clcccccc}
\hline Site & Medium & Cd & Cu & Cr & Hg & Mn & Zn \\
\hline \multirow{2}{*}{ I } & Plant & $0.096 \pm 0.004$ & $5.55 \pm 0.28$ & $1.71 \pm 0.08$ & $0.0243 \pm 0.0010$ & $67.3 \pm 1.74$ & $37.2 \pm 1.24$ \\
& Sediment & 0.231 & 2.87 & 2.13 & 0.035 & 175.8 & 9.41 \\
& Water & 0.0001 & 0.003 & 0.01 & 0.0008 & 0.0032 & 0.0027 \\
II & Plant & $3.219 \pm 0.17$ & $26.46 \pm 0.79$ & $8.00 \pm 0.16$ & $0.0429 \pm 0.0019$ & $502.4 \pm 5.12$ & $90.1 \pm 0.45$ \\
& Sediment & 0.409 & 15.81 & 14.95 & 0.0666 & 49,921 & 137.29 \\
& Water & 0.00027 & 0.005 & 0.012 & 0.0011 & 0.0259 & 0.0034 \\
III & Plant & $0.259 \pm 0.004$ & $5.18 \pm 0.25$ & $3.15 \pm 0.20$ & $0.0270 \pm 0.0021$ & $86.3 \pm 1.30$ & $68.8 \pm 0.78$ \\
& Sediment & 0.400 & 8.14 & 4.84 & 0.0287 & 1390.9 & 44.42 \\
& Water & 0.0008 & 0.005 & 0.01 & 0.0009 & 0.0091 & 0.0050 \\
\hline
\end{tabular}

Onaindia et al. [20] stated that G. densa is a plant characteristic of clean waters, while Segota et al. [21] suggests that this species inhabits diverse aquatic habitats with varying water parameters. The study of Ot'ahel'ova' et al. [22] and Kohler and Schneider [23] demonstrated that high population densities of $G$. densa are found on slightly eutrophic localities. Data presented in Table 1 suggest that the studied sites differed considerably only in the bottom type, amount of organic sediments present and the water course depth.

Out of the three sites with reintroduced G. densa, the highest concentrations of the analyzed elements both in sediments and water were found at the site in the urbanized catchment-site II.

In general, the rate of absorption, accumulation, and translocation of metal in plants depends on plant species and is further regulated by environmental factors like the chemical speciation of the metal, temperature, $\mathrm{pH}$, redox potential, and salinity [24]. The content of metals in bottom sediments is an indicator of their long-term accumulation in reservoirs and watercourse sediments [25]. The content of the investigated elements in the sediments was low in the majority of cases and it remained within the range of geochemical background and first geochemical class [26]. In most points, Ig and CF indices show natural content of the studied elements (Ig) or low level contamination (CF) of the sediments collected from sites I and III (Tables 3 and 4). In the case of sediments collected from site II, only cadmium concentration was found to be very low, whereas the remaining trace metals exceeded the background value and this classified the sediments as moderately contaminated (CF) (Table 4).

In terms of ecotoxicological criteria, the studied sediments were characterized by concentrations below which no harmful effect on benthic organisms is envisaged (TEC), with the exception for manganese in the II and III study sites, which exceeded their PEC - threshold content of the element, above which toxic influence on benthos organism is observed (Table 4). G. densa tolerates elevated manganese concentrations because it prefers spring-fed, oxygenated and mineralized waters. Under the conditions of Western Pomerania, groundwater in postglacial areas is characterized by high concentrations of $\mathrm{Fe}$ and $\mathrm{Mn}$. 
Table 4. Sediment contamination classes according to geochemical index (Igeo) and contamination factor $(\mathrm{CF})$ indicators and to ecotoxicological criteria indices.

\begin{tabular}{|c|c|c|c|c|c|c|c|}
\hline Site & Indicator & $\mathrm{Cd}$ & $\mathrm{Cr}$ & $\mathrm{Cu}$ & $\mathrm{Hg}$ & Mn & $\mathrm{Zn}$ \\
\hline \multirow{3}{*}{ I } & Igeo & 0 & 0 & 0 & 0 & & 0 \\
\hline & $\mathrm{CF}$ & 1 & 1 & 1 & 1 & - & 1 \\
\hline & $\begin{array}{l}\text { ecotoxicological } \\
\text { criteria } \\
\text { indices }\end{array}$ & $<\mathrm{TEC}$ & $<\mathrm{TEC}$ & $<\mathrm{TEC}$ & $<\mathrm{TEC}$ & $<$ TEC & $<\mathrm{TEC}$ \\
\hline \multirow{3}{*}{ II } & Igeo & 0 & 1 & 1 & 0 & - & 1 \\
\hline & $\mathrm{CF}$ & 1 & 2 & 2 & 2 & - & 2 \\
\hline & $\begin{array}{l}\text { ecotoxicological } \\
\text { criteria } \\
\text { indices }\end{array}$ & $<\mathrm{TEC}$ & $<$ TEC & $<$ TEC & $<\mathrm{TEC}$ & $>$ PEC & $>\mathrm{TEC}<\mathrm{MEC}$ \\
\hline \multirow{3}{*}{ III } & Igeo & 0 & 0 & 0 & 0 & - & 0 \\
\hline & $\mathrm{CF}$ & 1 & 1 & 2 & 1 & - & 1 \\
\hline & $\begin{array}{l}\text { ecotoxicological } \\
\text { criteria } \\
\text { indices }\end{array}$ & $<\mathrm{TEC}$ & $<\mathrm{TEC}$ & $<\mathrm{TEC}$ & $<\mathrm{TEC}$ & $>$ PEC & $<\mathrm{TEC}$ \\
\hline
\end{tabular}

The mean heavy metal content of the sediments and aquatic macrophytes are described in descending order of $\mathrm{Mn}>\mathrm{Zn}>\mathrm{Cu}>\mathrm{Cr}>\mathrm{Cd}$ in many cases [24]. A similar relationship was determined in the present research. In all tested points the order of metal content in G. densa and sediments was as follows: $\mathrm{Mn}>\mathrm{Zn}>\mathrm{Cu}>\mathrm{Cr}>\mathrm{Cd}>\mathrm{Hg}$ (Table 3).

The lowest content of the studied elements ( $\mathrm{Hg}, \mathrm{Cd}, \mathrm{Cr}, \mathrm{Cu}, \mathrm{Zn}$ and $\mathrm{Mn}$ ) was determined in plant samples collected from the control point - site I, and these were, respectively: $0.0243 ; 0.096 ; 1.71 ; 5.55 ; 37.2$ and $67.3 \mathrm{mg} \cdot \mathrm{kg}^{-1}$ (Table 3 ). On the other hand, the higher values of the investigated elements were found at site II, which is located in the agricultural basin with developed municipal and road infrastructure, as well as periodic runoff of municipal wastewater to the studied water course. The highest differences in the mean metal content of whole plants between the study points was found for cadmium, manganese, and copper. For the other elements tested (chromium, mercury, and zinc), the differences were lower (Table 3).

Cadmium content in G. densa observed in the present study was considerably lower (from 200 to 6 times) from the value determined by Kara and Zeytunluoglu [7] in control plants $\left(20 \mathrm{mg} \cdot \mathrm{kg}^{-1}\right)$ (Table 5). In turn, cadmium content in G. densa from sites I and III was similar to that in the plants analyzed by Ymlaz and Parlak [8], and 10 times higher in site II. The present study revealed lower (4.7-5.0 fold) copper content in G. densa from site I and III than in control plants in the study of Kara and Zeytunluoglu [7]. However, the value of copper in G. densa from site II was similar to the value provided by these authors.

In contrast to other aquatic plants, G. densa, reintroduced to West Pomerania, accumulates relatively low amounts of metals (Table 5). This confirms the study of Demirezen and Aksoy [5] who, when checking the usefulness of hydrophytes (Phragmites australis, Typha angustifolia, Potamogeton pectinatus, Ranunculus sphaerosphermus and G. densa) as bioindicators of iron and manganese pollution, found that Potamogeton pectinatus accumulated more heavy metals than G. densa.

Non-rooted macrophytes absorb their nutrients from water, and are consequently usually found in aquatic ecosystems where the nutrient level in the water column is high. Rooted plants can use nutrients both in the water column and in the substrate [27]. G. densa is characterized by a very poorly developed root system and the part of its shoots that is submerged in bottom organic sediments has no leaves. Cut-off from light has a destructive effect on this light-loving species and the leaves die. Figure 2 shows the accumulation of the studied elements in the separated parts of G. densa, the youngest 5-6 cm apical parts, 
the remaining leafy stem and the leafless part of this plant. The results obtained indicate that the distribution of these elements in plants is differentiated. In most cases, more metals were found in the leafy part of the stem below $5 \mathrm{~cm}$ of the apical part. Similar distribution of metals in the examined parts of plants was found for sites I and III (agricultural and forest catchment), while in relatively frequent cases these relations were opposite in plants collected from site II-urbanized catchment.

Table 5. Comparison of trace element content in G. densa with other aquatic plants.

\begin{tabular}{|c|c|c|c|}
\hline Plant & Element & Content & Reference \\
\hline Groenlandia densa & $\mathrm{Cd}, \mathrm{Cu}, \mathrm{Ni}$, & $\begin{array}{l}20 \mu \mathrm{g} \mathrm{Cd} \cdot \mathrm{g}^{-1} \mathrm{~d} . w . \\
26 \mu \mathrm{g} \mathrm{Cu} \cdot \mathrm{g}^{-1} \mathrm{~d} . w . \\
14.39 \mathrm{mg} \mathrm{Ni} \cdot \mathrm{kg}^{-1} \text { d.w. }\end{array}$ & {$[7,8]$} \\
\hline Azolla filiculoides & $\begin{array}{l}\mathrm{Cd}, \\
\mathrm{Cr}, \\
\mathrm{Cu}, \\
\mathrm{Zn}\end{array}$ & $\begin{array}{l}\text { 2600-10,441 } \mathrm{mg} \mathrm{Cd} \cdot \mathrm{kg}^{-1} \\
\text { d.w. } \\
21.9-12,383 \mu \mathrm{g} \mathrm{Cr} \cdot \mathrm{g}^{-1} \\
\text { d.w. } \\
9224 \mathrm{mg} \mathrm{Cu} \mathrm{kg}^{-1} \mathrm{~d} . w . \\
6408 \mathrm{mg} \mathrm{Zn} \mathrm{g}{ }^{-1} \text { d.w. }\end{array}$ & {$[28,29]$} \\
\hline Eichhornia crassipes & $\mathrm{Cu}$ & $\begin{array}{l}6.41-34.3 \mathrm{mg} \mathrm{Cu} \cdot \mathrm{kg}^{-1} \\
62.9-67.9 \mathrm{mg} \mathrm{Mn} \cdot \mathrm{kg}^{-1} \\
0.037-0.13 \mathrm{mg} \mathrm{Cd} \cdot \mathrm{kg}^{-1}\end{array}$ & {$[30,31]$} \\
\hline Lemna minor & $\mathrm{Cr}$ & $2870 \mathrm{~g} \mathrm{Cr} \cdot \mathrm{kg}^{-1}$ d.w. & {$[15]$} \\
\hline Lemna gibba & $\mathrm{Cu}, \mathrm{Cd}, \mathrm{Zn}$ & $\begin{array}{l}10.9 \mu \mathrm{g} \mathrm{Cu} \mathrm{g} \mathrm{d.w.} \\
92.0 \mu \mathrm{g} \mathrm{Zn} \mathrm{g} \mathrm{d.w.} \\
4.4 \mu \mathrm{g} \mathrm{Cd} \mathrm{g} \mathrm{d.w.}\end{array}$ & [32] \\
\hline $\begin{array}{l}\text { Myriophyllum } \\
\text { spicatum }\end{array}$ & $\mathrm{Cd}$ & $2800 \mathrm{mg} \mathrm{Cd} \mathrm{g}^{-1}$ d.w. & {$[33]$} \\
\hline $\begin{array}{l}\text { Myriophyllum } \\
\text { aquaticum }\end{array}$ & $\mathrm{Cd}, \mathrm{Zn}$ & $\begin{array}{l}4300 \mu \mathrm{g} \mathrm{Zn} \mathrm{g}^{-1} \text { d.w. } \\
6.5 \mu \mathrm{g} \mathrm{Cd} \mathrm{g}^{-1} \text { d.w. }\end{array}$ & [34] \\
\hline Potamogeton pectinatus & $\mathrm{Cd}, \mathrm{Cu}, \mathrm{Mn}, \mathrm{Zn}$ & $\begin{array}{l}\text { 4.8-266 } \mu \mathrm{g} \mathrm{Cd} \mathrm{g}^{-1} \text { d.w. } \\
10.0 \mu \mathrm{g} \mathrm{Cu} \cdot \mathrm{g}^{-1} \text { d.w. } \\
60.0 \mu \mathrm{g} \mathrm{Zn} \mathrm{g}^{-1} \text { d.w. }\end{array}$ & {$[32,35]$} \\
\hline
\end{tabular}

The heavy metal accumulation indices calculated in the present study for G. densa relative to the content of these elements in sediments and in water indicate different accumulation capacity (Figure 3). BCF G/S $<1$ values were determined in the majority of studied cases, which suggest exclusion of these elements from plant tissues. However, the content of studied elements in $G$. densa with regards to their content in the water inhabited by the studied plant point to accumulation of these metals in plant tissues. It is assumed that a good heavy metal accumulator should be characterized by BCF values in excess of 1000 [15]. This condition was met by G. densa for manganese, zinc and cadmium. The bioaccumulation capacity of $G$. densa was relatively high given the low metal concentration in water, with the highest accumulation for Zn at site II, very high for Mn at sites I and II and high for Cd at site II. However, the comparison of concentration of metal levels in water, sediments and plant suggests that $\mathrm{Mn}$ has been accumulated only when applied by water, not by the substrate. This could result from very high concentrations of Mn in groundwater in postglacial areas as well as the ability of $G$. densa to remove manganese from water. The study of Kara and Zeytunluoglu [7] demonstrated that G. densa can be used to purify wastewater of $\mathrm{Cd}$ and $\mathrm{Cu}$, the maximum BCFG/w values obtained by these authors were 724 for $\mathrm{Cd}$ and 1.669 for $\mathrm{Cu}$. 


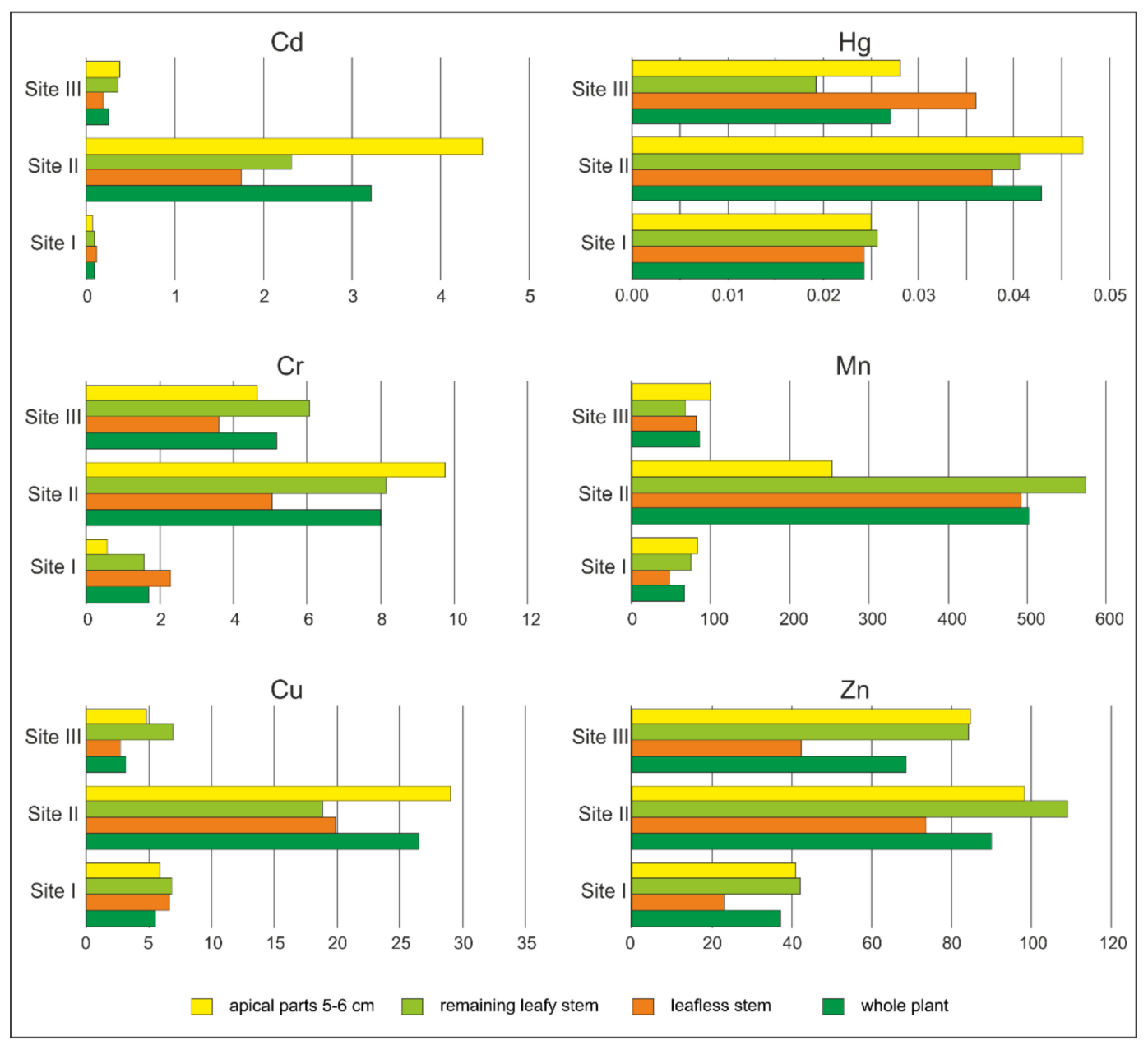

Figure 2. Accumulation of the studied elements $\left(\mathrm{mg} \cdot \mathrm{kg}^{-1} \mathrm{~d} . \mathrm{m}.\right)$ in the separated parts of G. densa.

The calculated correlation coefficients suggest a significant positive relationship between mercury content in the plant and the length of leaf blade, and between manganese content in the plant and the content in the sediments (Table 6). Although the values of correlation coefficients between leaf blade length and width with $\mathrm{Cd}, \mathrm{Mn}$ and $\mathrm{Cu}$ content were almost as high as mentioned above, the statistical analysis did not prove a significant positive relationship, probably due to a limited number of samples.

Table 6. Pearson linear correlation coefficient of G. densa shoot biometric parameters.

\begin{tabular}{cccccc}
\hline Element & Sediments & Water & $\begin{array}{c}\text { Length of Leaf } \\
\text { Blade }\end{array}$ & $\begin{array}{c}\text { Width of Leaf } \\
\text { Blade }\end{array}$ & $\begin{array}{c}\text { Internode } \\
\text { Length }\end{array}$ \\
\hline $\mathrm{Cd}$ & 0.577 & -0.240 & 0.989 & 0.981 & 0.189 \\
$\mathrm{Cu}$ & 0.872 & 0.417 & 0.960 & 0.944 & 0.050 \\
$\mathrm{Cr}$ & 0.928 & 0.835 & 0.924 & 0.942 & 0.664 \\
$\mathrm{Hg}$ & 0.958 & 0.980 & $\mathbf{0 . 9 9 \mathbf { 8 } ^ { \mathbf { 1 } }}$ & 0.994 & 0.274 \\
$\mathrm{Mn}$ & $\mathbf{0 . 9 9 9}$ & 0.977 & 0.988 & 0.979 & 0.181 \\
$\mathrm{Zn}$ & 0.933 & 0.402 & 0.902 & 0.924 & 0.702 \\
\hline
\end{tabular}

${ }^{1} p<0.05 . N=2$. 

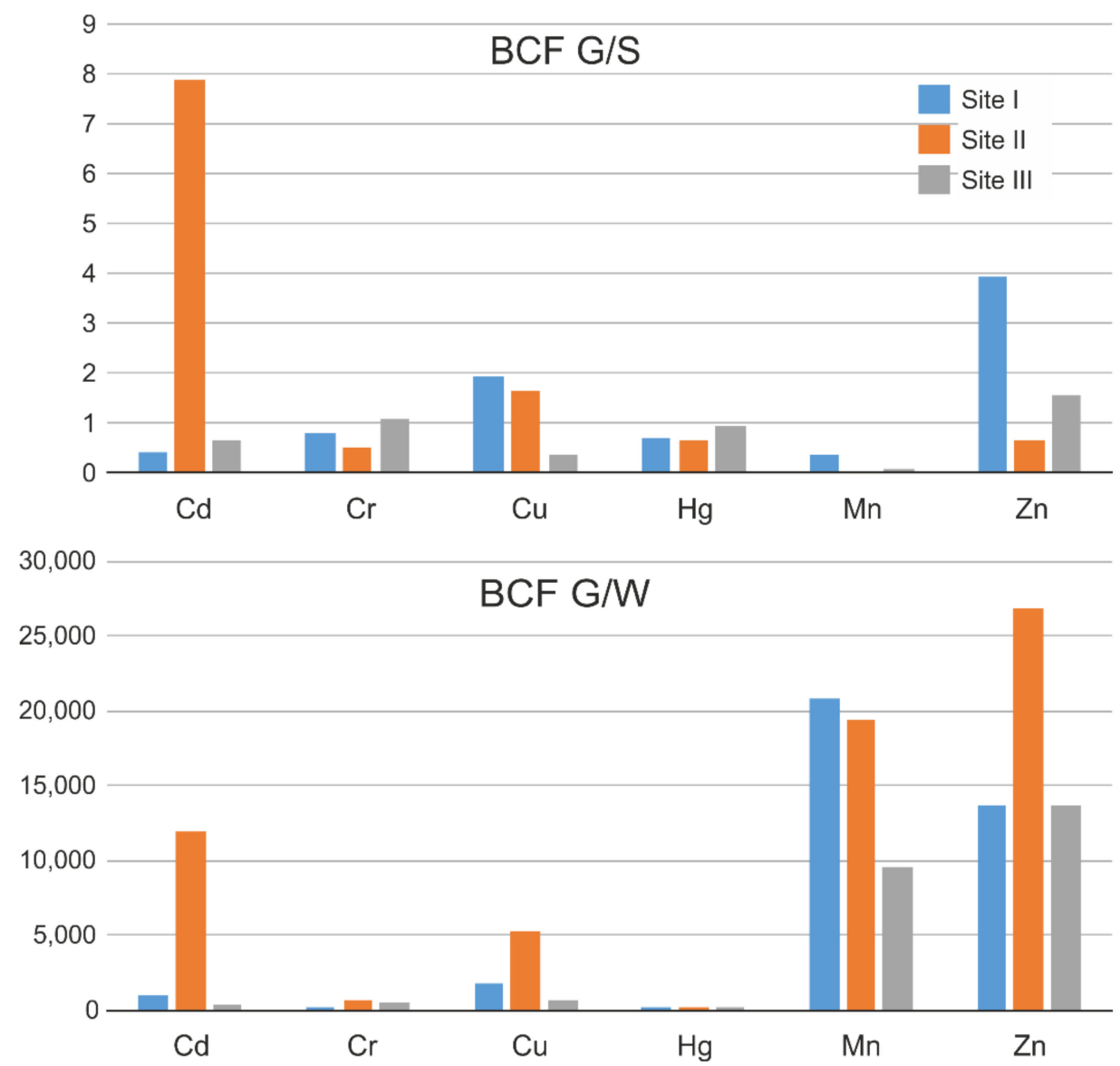

Figure 3. The bioconcentration factor (BCF) values of studied elements in G. densa with respect to the metal concentration in the substrate, where $G$ means concentration of studied elements in $G$. densa; S-in sediments, W-in water.

\section{Conclusions}

The study has shown a varied content of trace metals in Groenlandia densa reintroduced on 3 sites within Natura 2000 site in Western Pomerania.

Plants and sediments collected from the site with the highest human pressure contained higher amounts of metals. The order of metal content in G. densa and in the sediments in all test points was as follows: $\mathrm{Mn}>\mathrm{Zn}>\mathrm{Cu}>\mathrm{Cr}>\mathrm{Cd}>\mathrm{Hg}$. The calculated correlation coefficients suggest a significant positive relationship between mercury content and the plant and the length of leaf blade and between manganese content in the sediments.

The most anthropogenically loaded catchment within which the site with reintroduced G. densa was located was the urbanized catchment. Elevated amounts of copper, chromium, mercury and zinc were found in sediments from this watercourse, which classified the sediments as moderately contaminated.

The tolerance of $G$. densa to elevated Mn levels in water/sediment was confirmed, and was particularly pronounced at the site in an urbanized and forested catchment. The calculated correlation coefficients indicated a significant positive relationship between manganese content in the plant and its content in sediments as well as between mercury content and leaf blade length.

In most cases, higher concentrations of heavy metals were found in leafy shoots below the upper shoot segments and then in the apical parts of G. densa shoots compared to older, lower leafless segments of shoots submerged in bottom sediments.

The results obtained indicate the ability of $G$. densa to bioaccumulate and thus remove toxic compounds from flowing waters, although less efficiently than in laboratory conditions, and confirm the role of this critically endangered hydromacrophyte associated with 
the protected habitat of rivers characterized by Ranunculion fluitantis vegetation, and the need to maintain its gene pool in the waters of Western Pomerania.

Author Contributions: Conceptualization, J.P. and M.W.; methodology, J.P., M.W., J.S. and G.S.; software, J.P.; validation, J.P., J.S. and G.S.; formal analysis, J.P. and G.S.; investigation, J.P., M.W., J.S. and G.S.; resources, J.P., M.W., J.S. and G.S.; data curation, J.P. and J.S.; writing—original draft preparation, J.P. and M.W.; writing—review and editing, J.P., M.W., J.S. and G.S.; visualization, J.P.; supervision, J.P. and M.W.; project administration, M.W.; funding acquisition, M.W. All authors have read and agreed to the published version of the manuscript.

Funding: The work is the result of research carried out within the framework of the European project LIFE13 NAT/PL/000009 "Active protection of water-crowfoot habitats and restoration of wildlife corridor of the River Drawa basin in Poland". The project is co-financed by the European Commission and the National Fund for Environmental Protection and Water Management in Warsaw (NFOŚiGW).

Institutional Review Board Statement: Not applicable.

Informed Consent Statement: Not applicable.

Acknowledgments: The authors thank the Regional Directorate for Environmental Protection in Szczecin, the Botanical Garden of the Adam Mickiewicz University in Poznań and the Geoecological Station of the Adam Mickiewicz University in Storków for substantive cooperation in the project, support and organization of field work.

Conflicts of Interest: The authors declare no conflict of interest.

\section{References}

1. Rozporządzenie Ministra Środowiska z dnia 9 października 2014 r. w Sprawie Ochrony Gatunkowej Roślin. Dz.U. 2014, poz. 1409./Regulation of the Minister of Environment of 9 October 2014 on the Protection of Plant Species. Available online: http:/ / isap.sejm.gov.pl/isap.nsf/download.xsp/WDU20140001409/O/D20141409.pdf (accessed on 15 April 2021).

2. Kaźmierczakowa, R.; Bloch-Orłowska, J.; Celka, Z.; Cwener, A.; Dajdok, Z.; Michalska-Hejduk, D.; Pawlikowski, P.; Szczęśniak, E.; Ziarnek, K. Polish Red List of Pteridophytes and Flowering Plants; Institute of Nature Conservation, Polish Academy of Sciences: Krakow, Poland, 2016.

3. Kaźmierczakowa, R.; Zarzycki, K.; Mirek, Z. Polska Czerwona Księga Roślin; Instytut Ochrony Przyrody, Polska Akademia Nauk: Krakow, Poland, 2014.

4. Puchalski, W.; Cieślak, E.; Nowak, J.; Żukowski, W. Czy introdukcja Groenlandia densa (Potamogetonaceae) w Polsce ma szanse powodzenia? Fragm. Florist. Geobot. Pol. 2016, 23, 289-304.

5. Wróbel, M.; Furdyna, A.; Miller, T. Reintroduction of Groenlandia densa (L.) Fourr.-Experiences and suggestions. Biodivers. Res. Conserv. 2020, 60, 1-10. [CrossRef]

6. Demirezen, D.; Aksoy, A. Common hydrophytes as bioindicators of iron and manganese pollutions. Ecol. Indic. 2006, 6, 388-393. [CrossRef]

7. Kara, Y.; Zeytunluoglu, A. Bioaccumulation of Toxic Metals (Cd and $\mathrm{Cu}$ ) by Groenlandia densa (L.) Fourr. Bull. Environ. Contam. Toxicol. 2007, 79, 609-612. [CrossRef] [PubMed]

8. Yilmaz, D.D.; Parlak, K.U. Antioxidative parameters in the opposite-leaved pondweed (Groenlandia densa) in response to nickel stress. Chem. Speciat. Bioavailab. 2011, 23, 71-79. [CrossRef]

9. Maqbool Geelani, S.; Bhat, S.J.A.; Hanifa Geelani, S.; Haq, S. Pollution Indicators and Their Detection. J. Plant Sci. Res. 2012, 28, 193-197.

10. Karczewski, A. Morpho- and lithogenetic diversification of the Pomeranian phase in western and central Pomerania. Z. Geomorphol. 1994, 35-48.

11. Mazurek, M.; Kruszyk, R.; Szpikowska, G. Source-to-mainstream: Hydrochemical water changes in a channel head in the young glacial area (Pomeranian Lakeland, Poland). Geomorphology 2020, 371, 1-15. [CrossRef]

12. PN-EN ISO 10304-1: 2009E. Water Quality—Determination of Dissolved Anions by Ion Chromatography—Part 1: Determination of Bromides, Chlorides, Fluorides, Nitrates, Nitrites, Phosphates and Sulphates; British Standards Institution: London, UK, 2009.

13. PN-EN ISO 6878: 2006P. Water Quality—Determination of Phosphorus—Ammonium Molybdate Spectrometric Method; Polski Komitet Normalizacyjny: Warsaw, Poland, 2010.

14. PN-EN ISO 9963-1: 2001P. Water Quality-Determination of Alkalinity_Part 1: Determination of General Alkalinity and Alkalinity towards Phenolphthalein. Available online: https://www.sis.se/api/document/preview/18779/ (accessed on 15 April 2021).

15. Zayed, A.; Gowthaman, S.; Terry, N. Phytoaccumulation of trace elements by wetland plants: I. Duckweed. J. Environ. Qual. 1998, 27, 715-721. [CrossRef] 
16. Rahmani, G.; Stenberg, S. Bioremoval of lead from water using Lemna minor. Bioresour. Technol. 1999, 70, 225-230. [CrossRef]

17. Müller, G. Die schwermetallbelastung der sedimente des Neckars und Seiner Neben flusse: Eine Bestandsaufnahme. Chem. Ztg. 1981, 105, 157-164.

18. Haakson, L. An Ecological Risk Index for Aquatic Pollution Control, a Sediment-Ecological Approach. Water Res. 1980, 14, 975-1001. [CrossRef]

19. MacDonald, D.; Ingersoll, C.; Berger, T. Development and evaluation of consensus-based sediment development and evaluation of consensus-based sediment quality guidelines for freshwater ecosystems. Arch. Environ. Contam. Toxicol. 2000, 39, 20-31. [CrossRef]

20. Onaindia, M.; de Bikuña, B.G.; Benito, I. Aquatic Plants in Relation to Environmental Factors in Northern Spain. J. Environ. Manag. 1996, 47, 123-137. [CrossRef]

21. Šegota, V.; Zlatković, B.; Vukov, D.; Alegro, A.; Koletić, N.; Vuković, N.; Rimac, A. Status assessment of the rare aquatic plant Groenlandia densa (L.) Fourr. (Potamogetonaceae) in the Western Balkans. Bot. Lett. 2019, 166, 125-133. [CrossRef]

22. Ot'ahel'ová, H.; Valachovic ${ }^{`}$, M.; Hrivna' $k$, R. The impact of environmental factors on the distribution pattern of aquatic plants along the Danube River corridor (Slovakia). Limnologica 2007, 37, 290-302. [CrossRef]

23. Kohler, A.; Schneider, S. Macrophytes as bioindicators. Arch. Hydrobiol. 2003, 14, 17-31. [CrossRef]

24. Prasad, M.N.V.; Greger, M.; Aravind, P. Biogeochemical cycling of trace elements by aquatic and wetland plants: Relevance to phytoremediation. In Trace Elements in the Environment; Prasad, M.N.V., Sajwan, K.S., Naidu, R., Eds.; Taylor and Francis, CRC Press: Boca Raton, FL, USA, 2006; pp. 1-451.

25. Baldantoni, D.; Maisto, G.; Bartoli, G.; Alfami, A. Analyses of three native aquatic plant species to assess spatial gradients of lake trace element contamination. Aquat. Bot. 2005, 83, 48-60. [CrossRef]

26. Bojakowska, I.; Sokołowska, G. Geochemiczne klasy czystości osadów wodnych. Przegląd Geol. 1998, 46, 49-54.

27. Bornette, G.; Puijalon, S. Response of aquatic plants to abiotic factors: A review. Aquat. Sci. 2011, 73, 1-14. [CrossRef]

28. Sela, M.; Garty, J.; Tel-Or, E. The accumulation and the effect of heavy metals on the water fern Azolla filiculoides. New Phytol. 1989, 112, 7. [CrossRef]

29. Arora, A.; Saxena, S.; Sharma, D.K. Tolerance and phytoaccumulation of chromium by three Azolla species. World J. Microbiol. Biotechnol. 2006, 22, 97. [CrossRef]

30. Lu, J.; Fu, Z.; Yin, Z. Performance of Water Hyacinth (Eichhornia crassipes) System in the Treatment of Wastewater from a Duck Farm and the Effects of Using Water Hyacinth as Duck Feed. J. Environ. Sci. 2008, 20, 513-519. [CrossRef]

31. Prasad, B.; Maiti, D. Comparative study of metal uptake by Eichhornia crassipes growing in ponds from mining and nonmining areas-A field study. Bioremediat. J. 2016, 20, 144-152. [CrossRef]

32. Younis, A.M.; Nafea, E.M.A. Heavy metals and nutritional composition of some naturally growing aquatic macrophytes of Northern Egyptian Lakes. J. Biol. Environ. Sci. 2015, 6, 16-23.

33. Wang, M.; Liu, J.; Lai, J. Metals Pollution and Ecological Risk Assessment of Sediments in the Poyang Lake, China. Bull. Environ. Contam. Toxicol. 2019, 102, 511-518. [CrossRef]

34. Cardwell, A.J.; Hawker, D.W.; Greenway, M. Metal accumulation in aquatic macrophytes from southeast Queensland, Australia. Chemosphere 2002, 48, 653. [CrossRef]

35. Rai, U.N.; Tripathi, R.D.; Vajpayee, P.; Pandey, N.; Ali, M.B.; Gupta, D.K. Cadmium accumulation and its phytotoxicity in Potamogeton pectinatus (Potamogetonaceae). Bull. Environ. Contam. Toxicol. 2003, 70, 566. [CrossRef] 